\title{
Kelas Laktasi untuk Sukseskan ASI Eksklusif melalui NYUPIT (Penyuluhan dan Pijat Oksitosin)
}

\author{
$1 *$ Lia Dwi Prafitri, ${ }^{2}$ Nina Zuhana, ${ }^{3}$ Wahyu Ersila \\ ${ }^{1}$ Sarjana Fisioterapi, Fakultas Ilmu Kesehatan, UMPP \\ ${ }^{2}$ Diploma Tiga Kebidanan, Fakultas Ilmu Kesehatan, UMPP \\ ${ }^{3}$ Sarjana Fisioterapi, Fakultas Ilmu Kesehatan, UMPP \\ *Penulis korespondensi, email: L02Prafitri@gmail.com
}

(Received: 05 April 2021/Accepted: 17 April 2021/Published: 31 July 2021)

\begin{abstract}
Abstrak
Kesulitan dalam memberikan Air Susu Ibu (ASI) eksklusif masih menjadi masalah utama bagi ibu menyusui. Bagi ibu dan bayi ASI Eksklusif memudahkan terjalin ikatan kasih sayang yang mesra antara ibu dan bayi baru lahir merupakan keuntungan awal dari menyusu secara eksklusif. Kelas laktasi merupakan sarana yang diberikan supaya ibu atau calon ibu mendapatkan edukasi mengenai pentingnya ASI dan persiapan menyusui untuk menyukseskan pemberian ASI eksklusif. Pada kelas laktasi ini, selain ibu akan mendapatkan penyuluhan kesehatan mengenai manfaat ASI, ibu juga akan mendapatkan informasi tentang Inisiasi Menyusu Dini (IMD), perawatan payudara seperti pijat oksitosin, tehnik memerah dan menyimpan ASI. Tujuan dari kegiatan pengabdian kepada masyarakat ini adalah untuk meningkatkan pengetahuan dan keterampilan ibu menyusui untuk menyukseskan ASI eksklusif. Metode pendekatan dengan melakukan penyuluhan kesehatan tentang ASI eksklusif dan demonstrasi pijat oksitosin. Sasaran kegiatan ini adalah ibu menyusui yang berada di Wilayah Kerja Puskesmas Kedungwuni I Kabupaten Pekalongan. Waktu pelaksanaan selama 6 bulan, dimulai dari tahap identifikasi permasalahan mitra, pemberian penyuluhan kesehatan dan demonstrasi pijat oksitosin, evaluasi dilakukan selama kegiatan dengan melakukan pre dan post test menggunakan kuesioner pengetahuan ibu menyusui mengenai ASI eksklusif, monitoring, dan rencana tindak lanjut. Hasil dari kegiatan ini adalah meningkatnya pengetahuan dan keterampilan ibu menyusui dalam menyukseskan ASI eksklusif, sehingga dimungkinkan dapat menciptakan generasi penerus bangsa yang sehat dan berkualitas. Diharapkan adanya tindak lanjut dari tenaga kesehatan dan dinas kesehatan untuk mengadakan kelas laktasi di setiap wilayah.
\end{abstract}

Kata Kunci : ASI Eksklusif, Kelas Laktasi

\begin{abstract}
Difficulty from giving breastmilk exclusive is still become major problem for breastfeeding mothers. The influance of breastmilk exclusive for mother and baby is to easier establish a loving bond between both which is the first advantage of exclusive breasrfeeding. Lactation class is a fasilitation for mothers or future mothers to receive education about the importance of exclusive breastmilk and breastfeeding preparation for the success of exclusive breast milk. In this lactation class, mothers getting health education about the benefits of breastmilk, in the other hand mothers also will get information about Early Initiation of Breastfeeding, breast care for instances oxytocin massage, expressing techniques and storing exclusive breastmilk. The purpose of this community service activity is to rise the knowledge and skills of breastfeeding mothers for the success of exclusive breastmilk.The approach method by community health education about the exclusive breastfeeding and demonstration of oxytocin massage. The target of this social community is breastfeeding mothers on Kedungwuni I Community Health Center, Pekalongan Regency. The implementation time was 6 months, that begin from the identification of partner problems, providing health education and
\end{abstract}


demonstration of oxytocin massage, evaluation was carried out during the activity by conducting pre and post tests using a questionnaire knowledge of breastfeeding mothers regarding exclusive breastfeeding, monitoring, and follow-up plans. The result of this activity there was an improved in the knowledge and skills of breastfeeding mothers for the success of exclusive breastmilk, so that it is possible to create a healthy and quality future generation of the nation. The researcher hope that there will be a follow-up from health workers and health offices to hold lactation class in another regions.

\section{Keywords : Exclusive breastmilk, Lactation Class}

\section{Pendahuluan}

Tingginya angka kematian bayi dapat ditanggulangi apabila bayi mendapatkan asupan yang baik serta gizi yang mencukupi, yaitu dengan pemberian ASI eksklusif (Budiati, 2010). Data SDKI (Survei Demografi dan Kesehatan Indonesia) pada tahun 2012 diketahui bahwa jumlah bayi sebelum usia 6 bulan yang diberikan ASI eksklusif hanya 27,1\%. Hal ini menunjukkan bahwa pemberian ASI eksklusif masih sangat rendah (Falikhah, 2014).

WHO melaporkan bahwa pemberian ASI eksklusif hingga usia enam bulan dapat mencegah kematian lebih dari 200 ribu bayi setiap tahun. Hal ini menunjukkan bahwa betapa pentingnya pemberian ASI eksklusif bagi seluruh bayi di dunia. Pemberian ASI tetap bisa dilakukan walaupun ibu bekerja. Negara juga ikut serta dalam memberikan dukungan dalam pemberian ASI eksklusif melalui peraturan perundang-undangan yang sudah ditetapkan (Falikhah, 2014).

Data yang diperoleh dari Perinasia (2010) bahwa penyebab rendahnya cakupan ASI eksklusif karena rendahnya pengatahuan ibu dan keluarga tentang ASI dan bagaimana cara memberikan ASI yang benar kepada bayi, kurangnya pelayanan dan dukungan dari tenaga kesehatan tentang laktasi. Selain itu, rasa percaya diri ibu yang masih kurang sehingga memberikan susu formula kepada bayinya ataupun susu tambahan lainnya. Hal tersebut dilakukan supaya bayi berhenti menangis karena merasa lapar (Isyti'aroh, Nizmah, \& Rejeki, 2015).

Bayi yang mendapatkan ASI menyebabkan pertumbuhan yang baik karena akan mengalami kenaikan berat badan yang sesuai masanya setelah lahir, pertumbuhan setelah periode perinatal baik dan mengurangi obesitas. ASI dapat dianggap sebagai kekayaan Nasional. Apabila semua ibu menyusui bayinya, diperkirakan akan mengurangi devisa Negara untuk membeli susu formula. Pemberian ASI akan meningkatkan kualitas generasi penerus bangsa (Damayanti, Pritasari, \& Lestari, 2017).

Kecukupan pemberian ASI bisa dilihat dari perilaku bayi yang tenang, tidak rewel dan tidur pulas. Tetapi perlu juga diperhatikan bahwa kesuksesan pemberian ASI dipengaruhi oleh tingkat kenyamanan ibu pada saat menyusui (Suryani \& Astuti, 2013). Pijat oksitosin yang dilakukan pada ibu menyusui dengan memijat area vertebrae dapat membantu memperlancar proses pengeluaran ASI, ibu akan menjadi lebih puas dan senang sehingga hormon oksitosin akan bekerja secara maksimal (Kholisatin, Munir, \& Astutik, 2019). Hasil wawancara yang dilakukan kepada bidan desa bahwa belum pernah memberikan pendidikan kesehatan tentang pijat oksitosin kepada ibu menyusui baik dari tenaga kesehatan ataupun dari kader kesehatan. Media yang ada hanya berupa poster pijat oksitosin yang seringkali pesannya tidak tersampaikan secara langsung (Mayasari, Susanti, \& Livana, 2017).

Pengetahuan dan pemahaman menyusui yang benar sangat penting bagi ibu menyusui, baik kelebihan dan keuntungan pemberian ASI, teknik menyusui, dan kendala selama menyusui (Budiati, Setyowati, \& Helena, 2010). Motivasi ibu menyusui dalam memberikan ASI eksklusif dapat dilakukan dengan pemberian paket booster ASI meliputi edukasi, pemberian booklet, dan pijat oksitosin. Upaya yang dapat dilakukan untuk menyukseskan pemberian ASI ekslusif yaitu dengan dengan mengadakan kelas laktasi. Kegiatan kelas laktasi ini merupakan hasil dari penelitian yang dilakukan oleh Prafitri, Zuhana, \& Ersila, 
tahun 2020, bahwa ada pengaruh paket booster ASI terhadap pengetahuan dan motivasi ibu menyusui.

Berdasarkan hasil wawancara dengan bidan desa dan kader Puskesmas Kedungwuni I Kabupaten Pekalongan bahwa banyak yang belum mengetahui tentang ASI eksklusif. Tujuan dari kegiatan pengabdian masyarakat ini adalah meningkatkan pengetahuan dan keterampilan ibu untuk mensukseskan ASI eksklusif dengan NYUPIT (Penyuluhan dan Pijat Oksitosin).

\section{Metode}

\subsection{Penentuan Permasalahan Prioritas Mitra}

Berdasarkan permasalahan mitra pengabdian kepada masyarakat, maka kebutuhan dan kesepakatan dengan mitra telah dirumuskan prioritas permasalahan sebagai berikut:

a. Kurangnya pengetahuan mitra tentang ASI eksklusif, sehingga perlu dilakukannya pemberian informasi melalui penyuluhan kesehatan mengenai ASI eksklusif.

b. Kurangnya keterampilan mitra dalam melakukan upaya meningkatkan produksi ASI, sehingga perlu dilakukannya demonstrasi pijat oksitosin pada ibu menyusui.

\subsection{Metode Pendekatan yang Ditawarkan}

Secara keseluruhan, kegiatan pengabdian kepada masyarakat dilakukan dengan metode pendekatan sebagai berikut:

1) Penyuluhan dengan metode ceramah tanya jawab dan diskusi mengenai ASI eksklusif dan permasalahan ibu menyusui.

2) Demonstrasi praktik pijat oksitosin pada ibu menyusui menggunakan minyak zaitun, phantom payudara, dan handuk.

\subsection{Uraian Prosedur Kerja}

Pelaksanaan kegiatan pengabdian kesehatan masyarakat ini berlangsung selama 6 bulan (September 2018 - Februari 2019), pelaksanaan terbagi menjadi beberapa tahapan atau prosedur kerja, yaitu:

a. Tahap 1: melakukan identifikasi mitra melalui wawancara kepada bidan dan kader kesehatan untuk selanjutnya dilakukan pengurusan ijin secara administratif pada pihak Puskesmas Kedungwuni I untuk menjelaskan maksud dan tujuan pelaksanaan kegiatan Pengabdian kepada masyarakat.

b. Tahap 2: memberikan informasi kepada ibu menyusui dengan penyuluhan kesehatan tentang ASI eksklusif, meliputi pengertian ASI eksklusif, komposisi ASI, kandungan zat gizi ASI, manfaat ASI eksklusif, dampak tidak diberikan ASI eksklusif, faktor yang mempengaruhi pemberian ASI eksklusif, ASI eksklusif pada ibu bekerja dan permasalahan pada ibu menyusui yang dilakukan pada tiga tempat.

c. Tahap 3: mendemonstrasikan pijat oksitosin pada 3 tempat dengan menggunakan phantom, minyak zaitun, dan handuk kemudian melakukan praktik kepada salah satu ibu menyusui.

d. Tahap 4: melakukan evaluasi dan monitoring untuk mengetahui sejauh mana pemahaman mitra terhadap informasi yang telah diberikan kepada ibu menyusui dengan memberikan pre- dan posttest menggunakan kuesioner.

\subsection{Khalayak Sasaran}

Khalayak sasaran kegiatan pengabdian kepada masyarakat ini adalah ibu menyusui yang berada di wilayah kerja Puskesmas Kedungwuni I Kabupaten Pekalongan sejumlah 79 ibu menyusui.

\subsection{Keterkaitan}

Kegiatan pengabdian kepada masyarakat ini bekerjasama dengan Puskesmas Kedungwuni I Kabupaten Pekalongan sebagai penyedia tempat penyelenggaraan 
kegiatan sekaligus peserta kegiatan. Kegiatan yang berlangsung mendapat dukungan dari bidan desa setempat dan kader kesehatan.

\subsection{Rancangan Evaluasi}

Rancangan evaluasi yang dilakukan pada kegiatan ini adalah evaluasi proses, dimana dilakukan selama kegiatan dengan meminta mitra untuk mengisi kuesioner pre dan post test tentang pengetahuan ibu menyusui mengenai ASI eksklusif.

\section{Hasil dan Pembahasan}

\subsection{Pengetahuan Ibu Menyusui}

Penyuluhan dilakukan dengan menggunakan media power point dengan metode ceramah tanya jawab. Jumlah audiens yang hadir pada kegiatan penyuluhan adalah 79 ibu menyusui. Pada kegiatan pengabdian masyarakat ini dilakukan penyuluhan ASI eksklusif meliputi pengertian ASI eksklusif, komposisi ASI, kandungan zat gizi ASI, manfaat ASI eksklusif, dampak tidak diberikan ASI eksklusif, faktor yang mempengaruhi pemberian ASI eksklusif, ASI eksklusif pada ibu bekerja dan permasalahan pada ibu menyusui sebagai upaya untuk meningkatkan pengetahuan ibu supaya bisa menyukseskan ASI eksklusif. Kegiatan pengabdian kepada masyarakat yang dilaksanakan berjalan dengan lancar, antusiasme ibu menyusui baik selama mengikuti semua kegiatan, walaupun ada beberapa ibu yang membawa anaknya merasa gelisah karena rewel.

Pada saat penyuluhan, beberapa ibu menyusui mengatakan pernah mengalami masalah saat menyusui, seperti ASI keluar hanya sedikit, puting susu tidak menonjol, puting susu lecet, bahkan ada yang sudah mencoba untuk mengkonsumsi pelancar ASI. Pada saat berlangsungnya penyuluhan, audiens yang menanyakan tentang caranya meningkatkan produksi ASI. Pertanyaan yang disampaikan dapat terjawab dengan baik yaitu cara meningkatkan produksi ASI dengan memastikan bayi menyusu dengan efisien dan pastikan perlekatan yang baik, menyusui atau memerah sesering mungkin, meminta bantuan konselor menyusui untuk mengatasi masalah menyusui, istirahat yang cukup, percaya diri bahwa produksi ASI mencukupi kebutuhan bayi, melakukan pijat oksitosin, makan dan minum yang dipercaya sebagai booster ASI seperti tanaman bangun-bangun, daun katuk, kedelai, kacang hijau. Adapun hasil dari kegiatan penyuluhan kesehatan dapat dilihat pada Gambar 1.

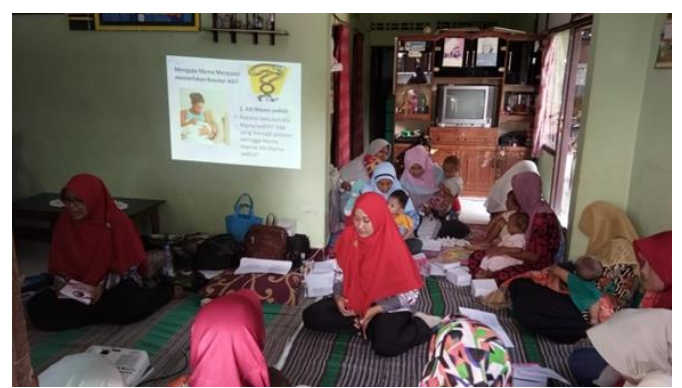

Gambar 1. Penyuluhan ASI Eksklusif

Gambar 1 merupakan kondisi pada saat dilakukan kegiatan penyuluhan yang dilakukan di Posyandu Desa Gembong, suasana kurang kondusif karena ada beberapa bayi yang rewel tetapi hal tersebut tidak mengurangi semangat audiens untuk mengikuti kegiatan penyuluhan dengan baik sampai selesai. Hal tersebut dapat diketahui dari hasil posttest yang dilakukan mengalami peningkatan pengetahuan ibu menyusui. Adapun hasil pre-dan posttest dapat dilihat pada Tabel 1. 
Tabel 1. Pengetahuan Ibu Menyusui Pre-dan Post diberikan Penyuluhan ASI Eksklusif

\begin{tabular}{lcccc}
\hline $\begin{array}{c}\text { Pengetahuan tentang } \\
\text { ASI Eksklusif }\end{array}$ & F & \% & F & Post \\
\hline Cukup & 46 & 58.2 & 5 & 6.3 \\
Baik & 33 & 41.8 & 74 & 93.7 \\
\hline \multicolumn{1}{c}{ Total } & $\mathbf{7 9}$ & $\mathbf{1 0 0}$ & $\mathbf{7 9}$ & $\mathbf{1 0 0}$ \\
\hline
\end{tabular}

Tabel 1 menunjukkan bahwa terdapat peningkatan pengetahuan ibu menyusui setelah diberikan penyuluhan ASI eksklusif meliputi pengertian ASI eksklusif, komposisi ASI, kandungan zat gizi ASI, manfaat ASI eksklusif, dampak tidak diberikan ASI eksklusif, faktor yang mempengaruhi pemberian ASI eksklusif, ASI eksklusif pada ibu bekerja dan permasalahan pada ibu menyusui. Hal tersebut mengindikasikan bahwa penerapan metode penyuluhan dapat secara efektif meningkatkan pengetahuan ibu menyusui tentang ASI eksklusif. Hasil penelitian Prafitri, Zuhana, \& Ersila, tahun 2020, mengatakan bahwa informasi yang didapatkan oleh responden dari teman, saudara, tenaga kesehatan maupun media hanya sedikit. Informasi tentang booster ASI sangat penting bagi ibu menyusui untuk membantu ibu meningkatkan kualitas dan kuantitas produksi ASInya sehingga ibu dapat menyusui bayinya dengan lancar secara eksklusif dan berlanjut sampai usia dua tahun.

Hasil penelitian lain mengatakan bahwa ibu yang diberikan paket "SUKSES ASI" mendapatkan kepuasan terhadap kelancaran produksi ASI-nya, serta puas karena produksi ASInya mencukupi kebutuhan bayi mereka. Paket "SUKSES ASI" yang diberikan meliputi pengkajian fisik pemeriksaan payudara serta memberikan booklet mengenai ASI (Budiati, Setyowati, \& Helena, 2010).

Kegiatan pengabdian masyarakat ini berdasarkan hasil penelitian dimana peneliti memberikan penyuluhan kesehatan mengenai booster ASI, membagikan booklet, mempraktikkan pijat oksitosin serta memperkenalkan produk yang dapat meningkatkan kualitas dan kuantitas ASI yaitu dengan susu kedelai kacang hijau. Adapun hasil penelitian tersebut bahwa ada pengaruh paket booster ASI terhadap pengetahuan dan motivasi ibu menyusui (Prafitri, Zuhana, \& Ersila, 2020).

Upaya yang sudah dilakukan oleh tenaga kesehatan dalam meningkatkan pemberian ASI yaitu konseling, pendampingan oleh keluarga, perawatan payudara dan hipnolaktasi. Hasil kegiatan pengabdian kepada masyarakat yang sudah dilakukan menunjukkan bahwa penyuluhan atau edukasi mengenai ASI eksklusif sangat membantu mitra dalam meningkatkan pengetahuannya. Upaya berupa penyuluhan, edukasi, ataupun konseling akan lebih baik apabila dilakukan sejak masa kehamilan sampai dengan ibu menyusui. Hal ini sejalan dengan hasil penelitian yang menyatakan bahwa konseling yang dilakukan setelah melahirkan mempunyai pengaruh terhadap pemberian ASI selama 4 sampai 6 minggu, sedangkan konseling yang dilakukan selama kehamilan dan setelah melahirkan mempunyai pengaruh terhadap pemberian ASI eksklusif sampai 6 bulan (Imdad, Yakoob, \& Bhutta, 2011).

Salah satu faktor yang berperan penting dalam keberhasilan ASI eksklusif adalah pengetahuan, sehingga upaya yang paling banyak dilakukan di masyarakat adalah dengan memberikan konseling secara dini kepada ibu dan keluarga supaya dapat memahami pentingnya pemberian ASI eksklusif. Selain itu, dukungan dari keluarga terdekat dan tenaga kesehatan juga mampu meningkatkan kepercayaan diri supaya mau memberikan ASI (Safitri \& Puspitasari, 2018). Edukasi menyusui dapat meningkatkan pemberian ASI eksklusif dan menurunkan tingkat tidak menyusui pada saat bayi lahir, yaitu kurang dari 1 bulan dan usia 1 sampai 5 bulan. Edukasi yang dilakukan secara berkelompok lebih berpengaruh dibandingkan dengan edukasi pada individu atau 
kelompok saja. Intervensi yang dilakukan di Negara berkembang mempunyai dampak yang lebih besar dibandingkan dengan intervensi yang dilakukan di Negara maju (Haroon, Das, Salam, Imdad, \& Bhutta, 2013)

\subsection{Pijat Oksitosin}

Demontrasi pijat oksitosin yang dilakukan pada saat kegiatan berlangsung bertujuan supaya ibu menyusui dapat mengerti, memahami, dan bisa mempraktikkan secara langsung di rumah dengan bantuan suami ataupun keluarga. Media yang digunakan untuk mendemontrasikan pijat oksitosin adalah phantom payudara, handuk, dan minyak zaitun (Gambar 2). Langkah-langkah pijat oksitosin, yaitu dimulai dari meminta ibu untuk duduk bersandar ke depan pada posisi tangan saling melipat ke atas meja, kepala diletakkan diatas lengan, melepas pakaian ibu, kemudian mengoleskan minyak zaitun/minyak kelapa pada tangan, memijat sepanjang kedua sisi tulang belakang ibu dengan kedua kepalan tangan, dengan ibu jari menunjuk ke depan, menekan kuat-kuat kedua sisi tulang belakang membentuk gerakan melingkar kecilkecil dengan kedua ibu jari, pada saat bersamaan, pijat kearah bawah pada kedua sisi tulang belakang, dari leher ke arah tulang belikat selama 2-3 menit. Audiens dapat memahami dan bisa melakukannya dengan baik, hal ini diketahui dari adanya audiens yang bersedia mempraktikkan secara langsung pada phantom dengan baik dan tidak ada audiens yang mengajukan pertanyaan yang disampaikan.

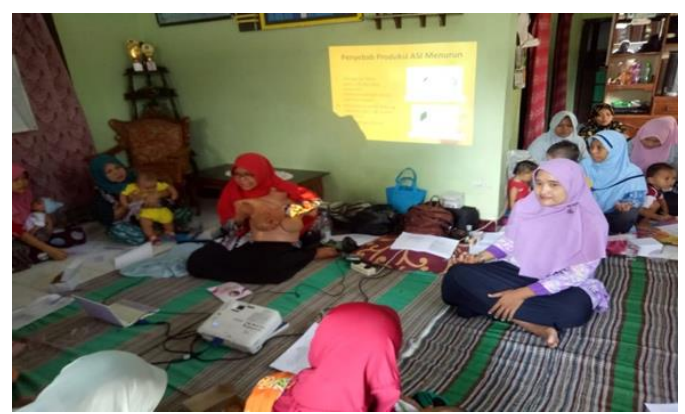

Gambar 2. Demonstrasi Pijat Oksitosin dengan Phantom Payudara

Pada saat demontrasi pijat oksitosin, para ibu menyusui kelihatan sangat antusias untuk memperhatikan dan ada tiga ibu yang ingin dilakukan pijat oksitosin secara langsung, serta ada juga ibu menyusui yang melakukan praktik pijat oksitosin dengan menggunakan phantom yang telah disediakan. Demonstrasi pijat oksitosin yang telah dilakukan secara langsung dapat membantu ibu menyusui untuk mengetahui tehnik yang dapat dilakukan ibu di rumah untuk dapat memperbanyak produksi ASI. Hal ini sesuai dengan hasil penelitian mengatakan bahwa pijat oksitosin mempengaruhi peningkatan berat badan bayi, frekuensi BAK bayi, frekuensi menyusu, dan lama tidur bayi. Hal ini menggambarkan bahwa pijat oksitosin mempengaruhi kelancaran ASI apabila dilihat dari indikator bayi (Suryani \& Astuti, 2013). Hasil penelitian Delima, Arni, \& Rosya, tahun 2016, menyatakan bahwa penelitiannya membuktikan pemijatan yang dilakukan sepanjang vertebrae akan merangsang adanya hormon prolaktin dan oksitosin, memberikan kenyamanan pada ibu, mengurangi bengkak serta mempertahankan produksi ASI.

Peningkatan produksi ASI dapat disebabkan karena adanya peningkatan rasa nyaman dan rileks pada saat diberikan pijat oksitosin. Adanya ibu yang tidak mengalami peningkatan produksi ASI dapat disebabkan oleh beberapa faktor, seperti umur, nutrisi, serta kondisi psikologis ibu karena kenyamanan, emosional, dan rasa tidak percaya diri (Saputri, Ginting, \& Zendato, 2019). Hal tersebut sejalan dengan pernyataan yang menyebutkan bahwa pijat oksitosin mampu meningkatkan 
kenyamanan dan produksi ASI ibu postpartum. Peningkatan produksi ASI ini disebabkan karena terjadinya peningkatan kenyamanan pada ibu yang secara otomatis akan merangsang keluarnya hormon oksitosin sehingga dapat merangsang pengeluaran ASI pada ibu menyusui (Rahayu, 2018).

Hasil penelitian lain menyatakan bahawa, berbagai jenis pijat payudara dilaporkan efektif dalam mengurangi rasa sakit langsung bagi ibu menyusui. Namun, kurangnya penjelasan rinci tentang teknik pijat payudara dan pelatihan ekstensif yang diperlukan untuk melakukan pijat payudara menurunkan kemampuan untuk mereplikasi hasil. Hasil ini mungkin berguna untuk profesional perawatan kesehatan ibu dengan masalah menyusui. Pijat payudara dapat menghilangkan rasa sakit dan mengatasi gejala yang terkait dengan kondisi yang mempengaruhi penghentian menyusui (Anderson, Kynoch, Kildea, \& Lee, 2019).

Hambatan yang terkait dengan menawarkan pijat payudara untuk semua ibu dengan masalah menyusui akan terus menjadi kendala sampai studi yang lebih bagus dilakukan. Secara keseluruhan, telah dibuktikan bahwa pijat payudara dalam bentuk apapun dengan cepat mengurangi rasa sakit pada ibu dan memungkinkan menyusui terus sampai gejala benar-benar hilang. Rujukan ke ahli kesehatan yang berpengalaman dalam pijat payudara direkomendasikan untuk ibu menyusui sebagai pilihan pengobatan tambahan untuk masalah menyusui (Anderson, 2019).

Kegiatan serupa juga dilakukan dengan menerapkan pendidikan kesehatan tentang ASI eksklusif melalui metode penyuluhan dan demonstrasi pada kader kesehatan, keluarga, ibu tentang ASI eksklusif, pijat oksitosin, tehnik menyusui yang benar, dan nutrisi masa menyusui pada mitra dan pendampingan pemberian ASI eksklusif pada ibu nifas (Wardhani, Dinastiti, \& Fauziyah, 2021). Hasil kegiatan lain yang dilakukan untuk program kesuksesan ASI eksklusif yang dilakukan pada kader dengan mengadakan pelatihan ASI eksklusif bagi para kader posyandu sebagai pemberi penyuluhan kesehatan kepada masyarakat di daerah sekitar, mengaplikasikan praktik dan demonstrasi, redemonstrasi kegiatan penyuluhan kesehatan tentang ASI eksklusif pada kader, mengevaluasi kader posyandu dalam proses penyuluhan kesehatan tentang ASI eksklusif pada ibu di Posyandu Balita. Hasil atau luaran dari kegiatan tersebut adalah meningkatnya kemampuan dan keterampilan para kader posyandu dalam memberikan penyuluhan kesehatan tentang ASI eksklusif dan mengoptimalisasikan peran kader posyandu dalam mensukseskan ASI eksklusif. (Handayani \& Aprilina, 2015).

Penulis dapat menyimpulkan bahwa kegiatan pengabdian kepada masyarakat untuk menyukseskan ASI eksklusif dapat dilakukan baik kepada ibu menyusui secara langsung ataupun kepada kader kesehatan. Metode yang dapat dilakukan yaitu penyuluhan dan demonstrasi ataupun praktik terkait dengan masalah menyusui.

\subsection{Dukungan Sekitar terhadap Kegiatan}

Proses kegiatan pengabdian kepada masyarakat yang dilaksanakan di Wilayah Kerja Puskesmas Kedungwuni I Kabupaten Pekalongan mendapat dukungan menyeluruh baik dari Puskesmas, bidan desa, kader kesehatan. Dukungan yang diberikan dapat terlihat dari antusiasme pihak Puskesmas dalam memberikan perijinan untuk kegiatan, Bidan desa yang membantu pelaksanaan selama kegiatan dan Kader Kesehatan yang memberikan fasilitas tempat pelaksanaan kegiatan.

\subsection{Hasil Refleksi}

Hasil refleksi dari kegiatan pengabdian kepada masyarakat ini adalah perlu dilakukan suatu upaya untuk membantu menyukseskan ASI eksklusif secara berkelanjutan dengan mengadakan kegiatan penyuluhan dan demontrasi pijat oksitosin serta masalah seputar menyusui secara terjadwal melaui kelas laktasi di semua wilayah kerja Puskesmas Kabupataen Pekalongan. Dalam hal ini perlu adanya kerjasama yang baik dari pihak terkait yaitu Dinas Kesehatan, Puskesmas, Bidan Desa dan Kader Kesehatan. 


\subsection{Hasil Luaran Kegiatan}

Hasil yang diperoleh dari kegiatan pengabdian kepada masyarakat ini adalah meningkatnya pengetahuan ibu menyusui tentang ASI eksklusif dan keterampilan pijat oksitosin pada ibu menyusui. Hal tersebut diharapkan dapat menyukseskan ASI eksklusif sehingga dapat meningkatkan persentase cakupan ASI eksklusif, menciptakan generasi penerus bangsa yang berkualitas serta menurunkan angka kematian pada bayi.

\subsection{Rencana Tindak Lanjut}

Rencana tindak lanjut dari kegiatan pengabdian kepada masyarakat ini adalah membentuk kelas laktasi di berbagai wilayah kerja Puskesmas di Kabupaten Pekalongan dengan mengadakan kerjasama pihak terkait yaitu Dinas Kesehatan, Puskesmas, Bidan Desa dan Kader Kesehatan yang akan dilaksanakan secara berkelanjutan untuk memberikan edukasi berupa penyuluhan dan konseling kepada ibu menyusui tentang ibu menyusui, ASI eksklusif, pijat oksitosin, serta materi lain tentang menyusui sehingga dapat menyukseskan ASI eksklusif di masa yang akan datang.

\section{Simpulan}

Kelas laktasi yang dilakukan dapat meningkatkan pengetahuan dan keterampilan ibu menyusui dalam menyukseskan pemberian ASI eksklusif sehingga dimungkinkan dapat menciptakan generasi penerus bangsa yang sehat dan berkualitas. Edukasi berupa penyuluhan ataupun konseling dari tenaga kesehatan dalam kelas laktasi yang berkelanjutan sangat diperlukan untuk dapat meningkatkan pengetahuan dan kesadaran ibu menyusui akan pentingnya pemberian ASI eksklusif yang mana dalam hal ini perlu adanya kerjasama dari pihak terkait yaitu dinas kesehatan serta tenaga kesehatan dan kader kesehatan.

\section{Persantunan}

Kami mengucapkan terima kasih kepada Lembaga Penelitian dan Pengabdian kepada Masyarakat Universitas Muhammadiyah Pekajangan Pekalongan yang sudah memberikan kesempatan kepada kami untuk melakukan kegiatan ini dan Puskesmas Kedungwuni I Kabupaten Pekalongan yang telah memberikan dukungan dalam pelaksanaan kegiatan pengabdian kepada masyarakat. Selain itu, kami juga mengucapkan terima kasih kepada bidan desa dan kader kesehatan yang telah banyak membantu dalam pelaksanaan kegiatan pengabdian kepada masyarakat ini sehingga kegiatan ini dapat berjalan dengan baik dan lancar.

\section{Referensi}

Anderson, L. (2019). Breast massage: can it keep mothers breastfeeding longer?. JIB Evidence Synthesis, 17(8), 1550-1551. doi: 10.11124/JBISRIR-D-19-00233.

Anderson, L., Kynoch, K., Kildea, S., \& Lee, N. (2019). Effectiveness of breast massage for the treatment of women with breastfeeding problems: a systematic review. National Library of Medicine, 17(8), 1668-1694. doi: 10.11124/JBISRIR-2017-003932.

Budiati, T., Setyowati, S., \& Helena, Cd, N. (2010). Peningkatan produksi ASI ibu nifas seksio sesarea melalui pemberian paket "SUKSES ASI". Jurnal Keperawatan Indonesia, 13(2), 59-66. doi: 10.7454/jki.v13i2.233.

Damayanti, D., Pritasari, P., \& Lestari, N. T. (2017). Gizi dalam daur kehidupan (1st ed.). Jakarta: Pusat Pendidikan Sumber Daya Manusia Kesehatan.

Delima, M., Arni, G. Z., \& Rosya, E. (2016). Pengaruh pijat oksitosin terhadap peningkatan produksi ASI ibu menyusui di Puskesmas Plus Mandiangin. Jurnal IPTEKS Terapan, 9(14), 283-293. doi: 10.22216/jit.2015.v9i4.1238.

Falikhah, N. (2014). ASI dan menyusui ( Tinjauan demografi kependudukan ). Jurnal Ilmu Dakwah, 13(26), 31-46. doi: 10.18592/alhadharah.v13i26.1707. 
Handayani, D. Y., \& Aprilina, H. D. (2015). Pemberdayaan kader posyandu dalam program ASI ekslusif di Desa Pamijem, Sokaraja, Banyumas. MEDISAINS: Jurnal Ilmiah Ilmu-ilmu Kesehatan, 13(1), 1-4.

Haroon, S., Das, J. K., Salam, R. A., Imdad, A., \& Bhutta, Z. A. (2013). Breastfeeding promotion interventions and breastfeeding practices: a systematic review. BMC Public Health, 13(Supp 3), S20. doi: 10.1186/1471-2458-13-S3-S20.

Imdad, A., Yakoob, M., \& Bhutta, Z. (2011). Effect of breast feeding promotion interventions on breast feeding rates, with special focus on developing countries. $B M J$ Public Health, 11(Suppl 3), S24. doi: 10.1186/1471-2458-11-S3-S24.

Isyti'aroh, I., Nizmah, N. F., \& Rejeki, H. (2015). Paket edukasi breast dan pengaruhnya terhadap kesuksesan ibu primipara dalam menyusui. Prosiding The 2nd University Research Coloquium, 563-569. Retrieved from https://jurnal.unimus.ac.id/index.php/psn12012010/article/view/1637.

Kholisatin, K., Munir, Z., \& Astutik, L. Y. (2019). Pengaruh pijat oksitosin terhadap pengeluaran ASI pada ibu post partum primipara di RSIA Srikandi IBI. Jurnal Keperawatan Profesional (JKP), 7(2), 1-13. doi: 10.33650/jkp.v7i2.598.

Mayasari, T. W., Susanti, Y., \& Livana, P. (2017). Pengaruh pijat oksitosin terhadap produksi ASI ibu menyusui. Jurnal Keperawatan, 9(1), 24-29. doi: 10.32583/keperawatan.9.1.2017.24-29.

Prafitri, L. D., Zuhana, N., \& Ersila, W. (2020). The effect of breastfeeding booster for breastfeeding mothers in Pekalongan Regency. SIKLUS: Journal Research Midwifery Politeknik Tegal, 09(01), 19-25. doi: 10.30591/siklus.v9i1.1406.g1076.

Rahayu, D., Yunarsih. (2018). Penerapan pijat oksitosin dalam meningkatkan produksi ASI ibu postpartum. Journals of Ners Community, 09(01), 8-14. doi: 10.5281/zenodo.1405371.

Safitri, A., \& Puspitasari, D. A. (2018). Upaya peningkatan pemberian ASI eksklusif dan kebijakannya di Indonesia. Journal of Nutrition and Food Research, 41(1), 13-20. doi: 10.22435/pgm.v41i1.1856.

Saputri, I. N., Ginting, D. Y., \& Zendato, I. C. (2019). Pengaruh pijat oksitosin terhadap produksi ASI pada ibu post partum. Jurnal Kebidanan Kesra (JKK), 2(1). doi: $10.35451 /$ jkk.v2i1.249.

Suryani, E., \& Astuti, E. W. K. (2013). Pengaruh pijat oksitosin terhadap produksi ASI ibu postpartum di BPM Wilayah Kabupaten Klaten. Jurnal Terpadu Ilmu Kesehatan, 2(2), 123-128. Retrieved from http://jurnal.poltekkessolo.ac.id/index.php/Int/article/view/69.

Wardhani, R. K., Dinastiti, V. B., \& Fauziyah, N. (2021). Pendidikan kesehatan untuk meningkatkan Asi eksklusif. Journal of Community Engagement in Health, 4(1), 149154. doi: 10.30994/jceh.v4i1.129. 